\title{
Open \\ Clinical presentation of Long QT Syndrome in a case series study in Iraq
}

DOI: https://doi.org/10.32007/jfacmedbagdad.6231753

\author{
Amar T. Alhamdi* $\quad$ MRCP(UK), FRCP(Ed.)
}

\section{(1) (3)}

This work is licensed under a Creative Commons Attribution-NonCommercial 4.0 International License.

\begin{abstract}
:
Background: Long QT syndrome is an important cause of arrhythmic death, and it is characterized by electrocardiographic changes and a prolonged QT interval. Patients may present with sudden cardiac death, recurrent syncope, and palpitation.

Objective: Clinical orientation for the Long QT syndrome and minimizing its misdiagnosis to achieve high diagnostic index.

JFac Med Baghdad 2020; Vol.62, No. 3 Received. May, 2020 Accepted Oct. 2020 Published:Nov. ,2020

Patients and Methods: Patients presenting with ventricular arrhythmias, syncope, dizzy spells, and prolonged, non-drug-induced QT interval from 2004 uptil 2019 at Al Nasirya Heart Center , Al Sulaimanya Heart Hospital, and Al Nahrain Teaching Hospital were enrolled in this study. All aptients studied clinically and followed up. Management included beta blocker drug therapy and ICD implantation.

Results: Forty-two patients were included within 15 years, comprising 22 pediatric and 20 adult patients (26 males, 16 females). Ventricular fibrillation reported in 18 patients and ventricular tachycardia in five patients. Thirty-eight patients received beta blockers, and $85 \%$ showed marked reduction in ventricular arrhythmia events. Implantable cardioverter-defibrillator (ICD) was implanted in 34 patients. The diagnosis of Long QT syndrome was missed in $85 \%$ of cases during the provisional medical contacts

Conclusion: In this case series study patients with LQTS presented with syncope, recurrent dizzy spells or palpitation. The diagnosis requires high index of diagnostic suspicion. This case study is intended to orient physicians to diagnosis this fatal problem.

Keywords: Long QT-syndrome, clinical presentation, Iraq.
\end{abstract}

\section{Introduction:}

Congenital long QT syndrome (LQTS) is a lifethreatening disease that represent an important cause of sudden death. It is characterized by ECG changes including prolonged QT interval and ventricular arrhythmias that cause symptoms of syncope, dizzy spells, and palpitations.1,2,3 People with LQTS may present with sudden cardiac death (SCD) due to ventricular fibrillation (VF), syncope, recurrent palpitations, or prolonged QT is incidentally found on routine electrocardiogram (ECG) for cardiac or noncardiac symptomatologies.4,5 If it is found during the evaluation of unexplained syncope, the diagnosis of ventricular arrhythmias resulting from LQTS becomes possible.6,7 LQTS may be misdiagnosed as epilepsy because of a syncope-like presentation. 8 Occasionally LQT may be seen in asymptomatic patients where ECG was obtained for other reasons.2,3 LQTS is commonly inherited but it can be caused by drugs when it should be distinguished from inherited LQTS.1,2 The incidence of LQTS among the general population is uncertain, but an incidence of 1/3000-1/20,000 has been reported.9 LQTS genotypes are mainly determined by mutations in many defined genes.10,

*Alhamdi Heart Clinic, Sulaimanya, Kurdistan

Region, Iraq. Email: amaralhamdi@yahoo.com
11, 12 LQTS1 (43\%), LQTS2 (45\%), and LQTS 3 (7\%) account for $95 \%$ of the identified mutations. Other LQTS 4, 5 ,6, 7 are rare .11-15 LQTS is a disease of cardiac repolarization that is expressed as corrected LQT (LQTc) at the superficial ECG, and there is a risk of syncope and seizures' attacks and SCD16. The ventricular tachycardia (VT) of the Torse de point (TdP) type can terminate spontaneously, resulting in syncope or it can degenerate into fatal VF and SCD. To date, there are 17 LQTS-susceptible genes, which accounts for approximately $85 \%$ of the clinical disease, but the most common three types are LQT1, which shows mutations in the KCNQ1, LQTS2, which shows in the $\mathrm{KCNH} 2$ gene, and LQTS3, which shows mutations in the KCN5A gene.1,2,12 LQTS treatment has developed remarkably since the use of Beta blockers (BB), left cardiac sympathetic denervation (LCSD), and implantable cardioverter defibrillator (ICD) implantation to prevent SCD and terminate VT and VF.17-19, 20,24-26 Mapping and ablation of ventricular premature beats (VPCs) that trigger VF has become possible, and it has remarkably reduced VF recurrence.27 In Iraq few reports of this condition was found and few local reports in the Arab 
countires.28-33 The aim of this clinical case study is studying the clinical presentation of long QT syndrome, minimize the misdiagnosis and offer the right treatment .

\section{Patients and Methods:}

The study design is a case series study. Patients were collected from Al Nasirya Heart Center in Thiqar governorate, Al Sulaimanya Heart Hospital in $\mathrm{Al}$ Sulaimanya governorate, and Al Nahrain Teaching Hospital in Baghdad from the January 2004 uptill November 2019. Patients who clinically presented with symptoms of dizzy spells, pre-syncope, syncope, palpitations, or resuscitated VF, and who were found to have a prolonged QTc by a 12-lead ECG according to their age and sex were included on this study. The cases either presented to the above mentioned cardiac centers or referred to the author for evaluation and further management. Previous medical contacts and misdiagnosis before the diagnosis of LQTS were investigated. A family history of SCD or LQTS was taken. Patients with a positive family history of SCD or LQTS were asked about their parent's consanguinity. ECG was obtained in all first degree family members of patients who were diagnosed with the condition to determine whether other members are affected by LQTS. Unexplained sudden death in young children and infants triggered family screening for the condition. The QT interval was measured manually using limb lead II or the lead that showed the longest QT interval. The measurement was performed independently by two electrophysiologists and the average of the two measurements was taken as the QT interval. The QTc interval was measured using the Bazzett formula $(\mathrm{QTc}=\mathrm{QT} / \mathrm{square}$ root of $\mathrm{RR}$ interval) to correct the QT interval. A QTc that was longer than $450 \mathrm{msc}$ in males and $460 \mathrm{msc}$ in females was considered to be prolonged. All patients had 24- or 48-hour Holter monitoring to observe the daily QTc variation, to detect rhythm disturbances and monitor $\mathrm{T}$ wave changes. The LQTS was diagnosed based on the presence of one of the followings three criteria: 1) QTc greater than $450 \mathrm{msc}$ in males or $460 \mathrm{msc}$ in females; 2) QTc of $440 \mathrm{msc}$ and T-wave (TW) abnormalities or sinus bradycardia; or 3) syncope in a family member of the LQTS or SCD patient and prolonged or borderline QTc interval. The rhythm disturbance in each patient was identified either using a 12-lead ECG and or Holter monitor in the emergency room or at the clinic. In addition to the long-QT interval, LQTS1 was diagnosed if the TW has a high amplitude and a broad base, and LQTS2 is indicated by bifid TW (biphasic) in the precordial leads and an ST-T segment that has a low amplitude at the limb leads. LQTS3 shows a peaked TW with a narrow base and it is preceded by a long isoelectric ST-T segment. Patients in whom drug intake causes a long QT like erythromycin, chloroquine, sotalol and tricyclic antidepressants were excluded, and electrolytes including the calcium level were normal in all patients. This excludes druginduced or electrolyte disturbances causing the long QTc. Patients over the age of 45 years had coronary angiogram, those with a normal coronary angiogram excluded ischemic heart disease. Those under the age of $45 \mathrm{y}$ did not go to coronary angiogram. Unfortunately, molecular genetic studies were not available in Iraq at the time this paper was written. The treatment offered to our patients included BB therapy in patients who tolerated the drug well and had no contraindications. ICD implantation was used if the LQTS patients had family history of SCD, documented VT/VF that was recurrent despite a maximal BB dose, or syncope with a family history of LQTS or SCD.

Descriptive statistics was used.

\section{Results :}

Forty-two patients where included in this study over the last 15 years. There were 22 pediatric patients with an age range of 8 months to 14 years. Twenty adult patients had an age range from 18 to 54 years. Patients were either referred to the author for evaluation and management after having been diagnosed with LQTS or the patients were diagnosed by the author when they presented with the following symptoms: Syncope in 26, dizzy spells in 12, palpitation in 20, and poorly controlled epilepsy in one patient. Some patients may have more than one symptom.There were 26 males and 16 females. Twenty-four $(57 \%)$ patients had a family history of SCD, while in 18 (43\%) patients, there was no family history of SCD or LQTS. All patients were Iraqis, of whom 24 were Arabs and 18 were Kurds. Among the patients who were enrolled, three of the families included in the study were consanguineous, Table (1). Medical consultation before reaching the diagnosis of LQTS was reported in $85 \%$ of children and $50 \%$ of adults, with an average of three consultations where the cases were misdiagnosed as anemia, retarded growth or unexplained syncope in children, anxiety and stress, unexplained palpitation or syncope and ischemic heart disease (IHD) in adults, Table (2). All children who were referred after a diagnosis of LQTS by their physicians had family history of SCD. Table (3) shows that monomorphic VT was diagnosed in five patients, Torse de Pointe (TdP) in three patients. One VT was induced during ventricular programmed stimulation (VPS) by an electrophysiological study. Resuscitated VF was seen in 18 patients who were diagnosed and treated using ICD, nine of them were documented clinically and 9 through the ICD. Atrial fibrillation was seen in four patients, among whom three were clinically documented and one was diagnosed by the ICD. Additionally, 2:1 atrioventricular block (AVB) was seen in one 45-year-old female patient, which was clinically documented. History,ECG and T-wave morphology suggested that $22(52 \%)$ patients had LQTS1, $16(38 \%)$ patients had LQTS2, and 4 (10\%) patients had LQTS3 (Table 2 and Figures 1, 2, and 3). There are eight cases where the ECG changes were not typical of one type, but dominantly showed LQTS1 and included as such, occasionally TW changes that did not fit classically with either LQTS2 or LQTS3 but included within LQTS2 (Figure 3). Thirty-eight patients received BB. 
In 32 patients, propranolol was the $\mathrm{BB}$ that was used in doses based on body weight in children (3-5 $\mathrm{mg} / \mathrm{kg} /$ day in divided doses). Four patients were taking atenolol, and two patients were on metoprolol. Sixteen patients were in the pediatric group and 22 patients were adults. Thirty-four patients underwent ICD implantation; Table (2).

We could not offer LCSD to four patients who needed this procedure because of their poor response to $\mathrm{BB}$ or because recurrent VF needed defibrillation by the ICD. The unavailability of LCSD was thoroughly discussed with thoracic surgeons, but we could not offer this type of therapy.

Table 1: Sociodemographic characteristics, presentation and family history of patients with LQTS

\begin{tabular}{|c|c|c|}
\hline \multicolumn{2}{|c|}{ Variables and categories } & No. $(\%)$ \\
\hline \multirow[t]{2}{*}{ Sex } & Male & $26(62)$ \\
\hline & Female & $16(38)$ \\
\hline \multirow[t]{2}{*}{ Age } & Pediatric: $8 \mathrm{M}-14 \mathrm{Y}$ & $22(52)$ \\
\hline & Adults: $18-54 \mathrm{Y}$ & $20(48)$ \\
\hline \multirow{4}{*}{$\begin{array}{l}\text { Presenting } \\
\text { symptoms }\end{array}$} & Syncope & $26(62)$ \\
\hline & Dizzy spells & $12(29)$ \\
\hline & Palpitation & $20(48)$ \\
\hline & Fits & $1(2)$ \\
\hline \multirow{2}{*}{$\begin{array}{l}\text { Family history } \\
\text { SCD }\end{array}$} & Positive & $24(57)$ \\
\hline & Negative & $18(43)$ \\
\hline \multirow[t]{2}{*}{ Ethnicity } & Arabs & $24(57)$ \\
\hline & Kurds & $18(43)$ \\
\hline \multicolumn{2}{|c|}{ Consanguinous Families } & $3(7)$ \\
\hline \multicolumn{2}{|c|}{ Total } & $42(100)$ \\
\hline
\end{tabular}

Table 2: Distribution of the cases by selected clinical variables

\begin{tabular}{|c|c|c|c|}
\hline \multicolumn{2}{|c|}{ Variables and categories } & $\begin{array}{ll}\text { Paediatric } & \text { No. } \\
(\%) & \end{array}$ & $\begin{array}{l}\text { Adult No. } \\
(\%)\end{array}$ \\
\hline \multirow{3}{*}{$\begin{array}{l}\text { Type of } \\
\text { LQTS }\end{array}$} & LQTS1* & $22(52)$ & \\
\hline & LQTS2 & $16(38)$ & \\
\hline & LQTS3 & $4(10)$ & \\
\hline \multirow{4}{*}{\multicolumn{2}{|c|}{$\begin{array}{lr}\text { Provisional diagnosis at } \\
\text { initial } & \text { medical } \\
\text { presentation } & \text { before } \\
\text { LQTS was diagnosed }\end{array}$}} & Anemia: 12 & IHD: 10 \\
\hline & & $\begin{array}{l}\text { Retarded growth: } \\
5\end{array}$ & $\begin{array}{l}\text { Anxiety \& } \\
\text { stress: } 7\end{array}$ \\
\hline & & Unexplained & \\
\hline & & syncope: 19 & $\begin{array}{l}\text { Unexplained } \\
\text { syncope \& } \\
\text { palpitation: } \\
4\end{array}$ \\
\hline \multirow[t]{4}{*}{$\begin{array}{l}\text { Treatment } \\
\text { modalities }\end{array}$} & $\begin{array}{l}\text { BB: } \\
\text { Propranolol }\end{array}$ & 16 & 16 \\
\hline & $\begin{array}{l}\text { BB: } \\
\text { Atenolol }\end{array}$ & 0 & 4 \\
\hline & $\begin{array}{l}\text { BB: } \\
\text { Metoprolol }\end{array}$ & 0 & 2 \\
\hline & ICD & 18 & 16 \\
\hline \multirow{2}{*}{\multicolumn{2}{|c|}{ Total }} & 22 & 20 \\
\hline & & 42 & \\
\hline
\end{tabular}

Table 3: Distribtion of the types of arrhythmia encountered in LQTS patients and method of diagnosis

\begin{tabular}{|c|c|c|c|c|}
\hline \multirow{2}{*}{$\begin{array}{l}\text { Type of } \\
\text { arrhythmia }\end{array}$} & \multicolumn{3}{|l|}{ Diagosis } & \multirow{2}{*}{$\begin{array}{l}\text { Tota } \\
1\end{array}$} \\
\hline & $\begin{array}{l}\text { Clinical } \\
\text { diagnosi } \\
\mathrm{s}\end{array}$ & $\begin{array}{l}\text { Electro- } \\
\text { physiologic } \\
\text { al testing }\end{array}$ & $\begin{array}{l}\text { Implantable } \\
\text { cardioverter } \\
\text { defibrillator }\end{array}$ & \\
\hline $\begin{array}{l}\text { Monomorph } \\
\text { ic }\end{array}$ & 4 & 1 & & 5 \\
\hline
\end{tabular}

\begin{tabular}{llll}
\hline $\begin{array}{l}\text { ventricular } \\
\text { tachycardia }\end{array}$ & & & \\
\hline $\begin{array}{l}\text { Torse de } \\
\text { Pointes }\end{array}$ & 2 & 1 & 3 \\
\hline $\begin{array}{l}\text { Resuscitated } \\
\text { ventricular } \\
\text { fibrillation }\end{array}$ & 9 & 9 & 18 \\
\hline $\begin{array}{l}\text { Atrial } \\
\text { fibrillation }\end{array}$ & 3 & 1 & 4 \\
\hline $\begin{array}{l}2: 1 \quad \text { Atrio- } \\
\text { ventricular } \\
\text { block }\end{array}$ & 1 & & 1 \\
\hline
\end{tabular}

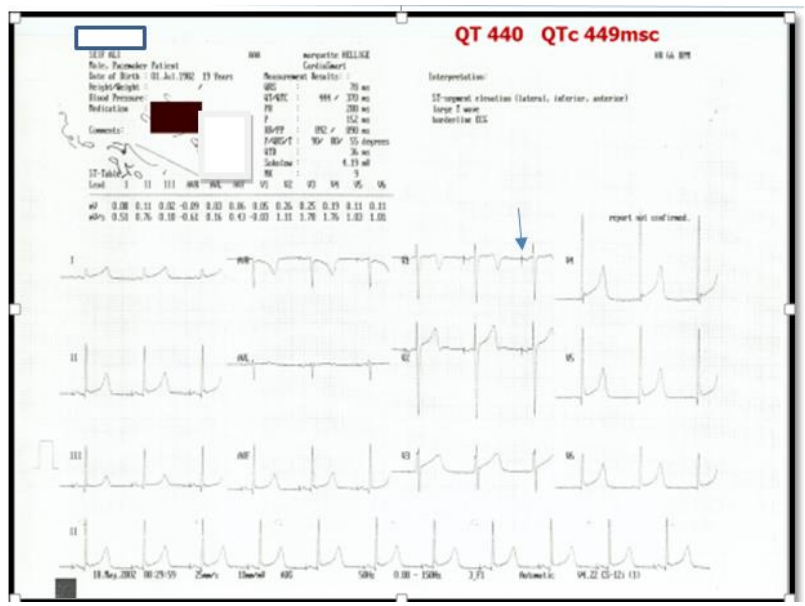

Figure 1A: ECG from a 20-year-old member of a family with LQTS .

The ECG in figure (1 A) shows a QTc of 449 msc and a broad base peaked TW, which suggests LQTS1. Atrial pacing by the dual chamber ICD that was implanted in this patient is indicated by the arrow. Figure (1 B) shows the dual chamber ICD endocardiogram (EGM) of defibrillated VF in the same patient.

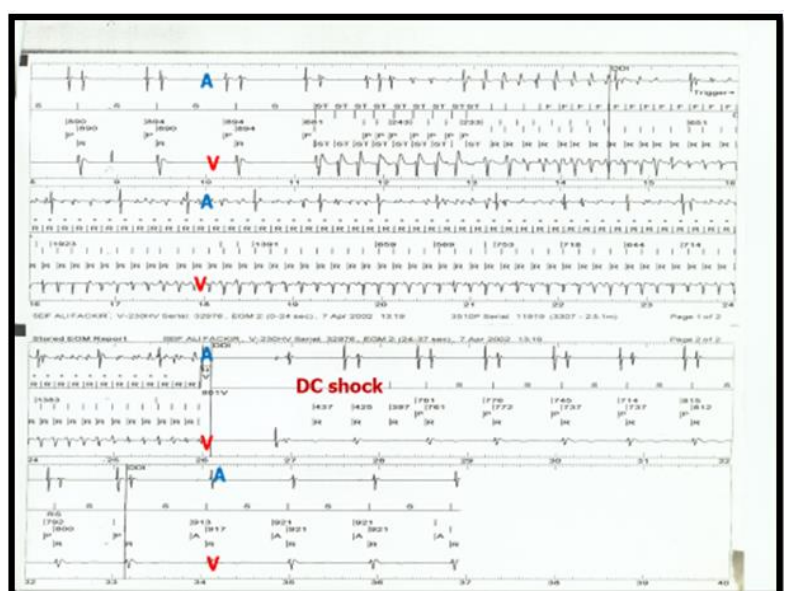

Figure 1B: Dual chamber ICD endocardiogram of defibrillated VF.

A, atrial signal; V, ventricular signal 


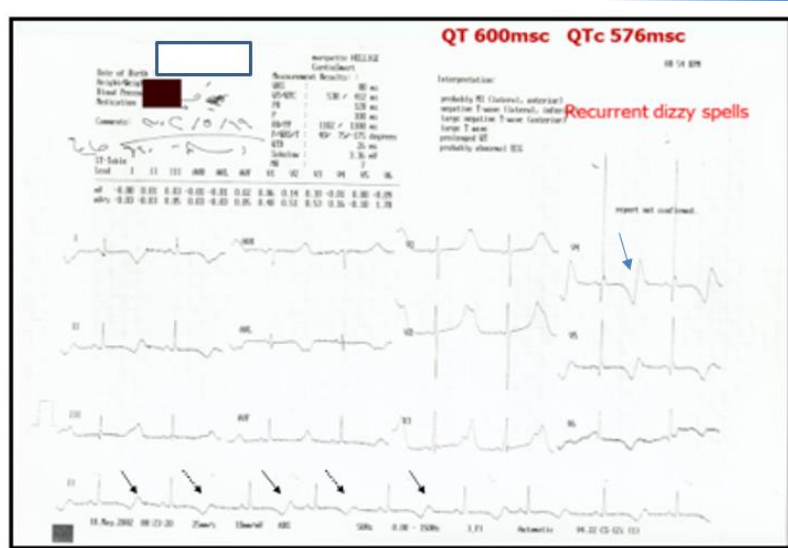

Figure 2, Twelve leads ECG of $12 \mathrm{y}$ age boy(brother of patient in Figure 1).Showing a QTe of $576 \mathrm{msc}$ with bifid, biphasic and inverted TW(arrow) suggesting a LQTS2, In lead II strip, please note beat to beat variation in $T$-wave shape and amplitude (solid arrows)which is called $\mathrm{T}$ wave alternance(TWA), a risk marker in LQTS (see text for details).

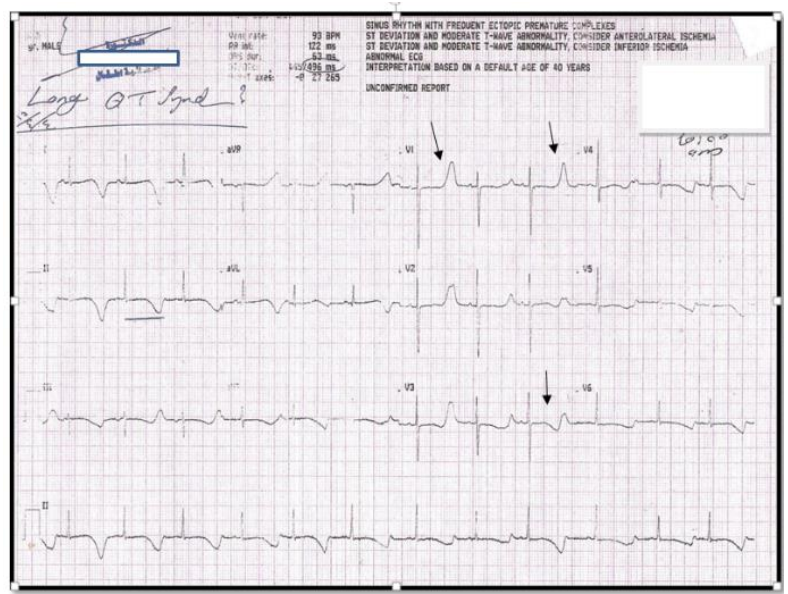

Figure (3) is a 12-lead ECG from a 4-year-old boy with LQTS showing a QTe of 644 msc and a TW at $\mathrm{V} 1$ with a high peak and narrow base, which suggests LQT3 (arrow). In leads V4, V5, and V6, a bifid TW is visible, suggesting LQT2 (arrow). There was a change in TW in the strip lead II at the bottom.

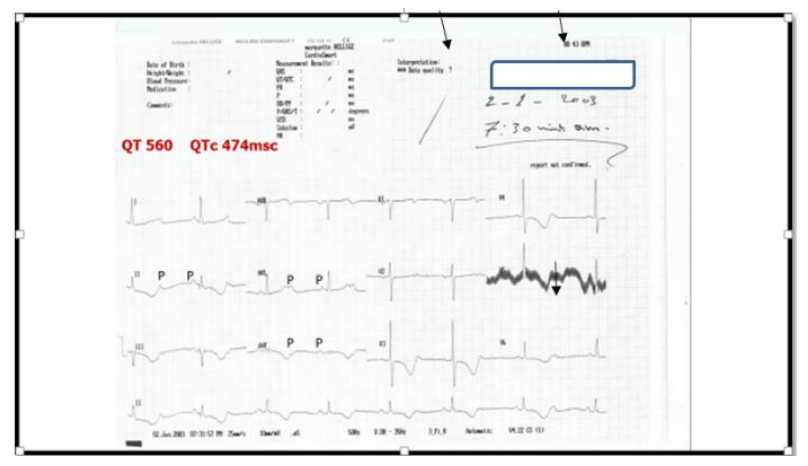

Figure 4A. A 12-lead ECG of a 45-year-old woman with 2:1 AVB and a prolonged QTc of $474 \mathrm{msc}$

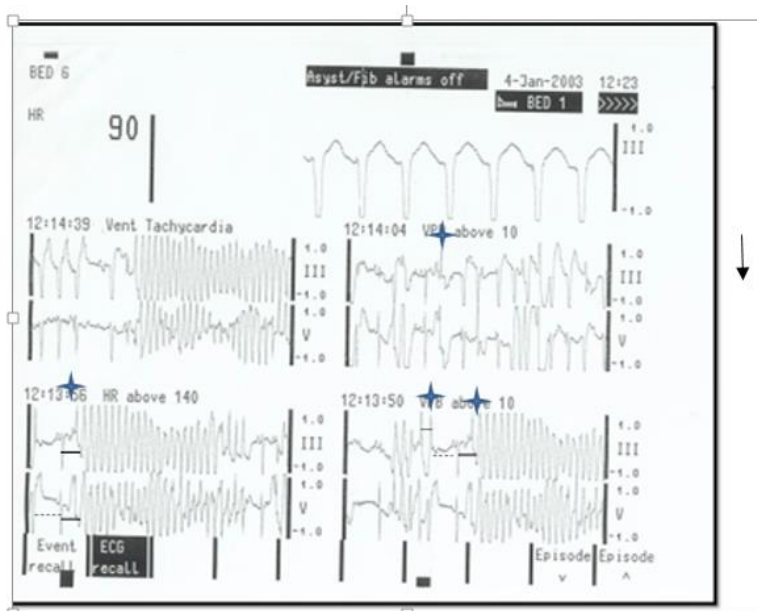

Figure 4B. Torse de pointes (Tdp) in the same patient as in Figure 4A.

Tdp is typically initiated by a short-long-short interval. Figure (4B) shows a premature ventricle complex (PVC) (asterisk) follows shortly after the sinus beat (short, solid line). The PVC is followed by a compensatory pause (long, dashed line). The following beat has a longer QT interval. If the next beat follows shortly thereafter, there is a good chance that this third beat falls within the QT interval, resulting in the $\mathrm{R}$ on $\mathrm{T}$ phenomenon and subsequent Tdp is preceded by a short (solid line), long (dashed line), and short (solid line) coupling interval.

\section{Discussion:}

Based on the history of symptoms and triggers, family history, and ECG changes in our series, we found that LQTS1 was the most common type, which comprised $52 \%$ of the cases, while LQT2 comprised $38 \%$ and LQT3 comprised $10 \%$ of the cases. This finding is comparable with other findings such as those in Schwartz and Moss' series.1,5 Misdiagnosis of LQTS during the first, second and even a third medical contact occurred in $85 \%$ of our cases before the LQTS diagnosis was made. The strongest part of their medical history was the positive family history of SCD to suggest a diagnosis of LQTS to the physician. The unavailability of genetic testing in Iraq negatively affected the detailed understanding of the phenotypes and genotypes of LQTS, and could not be compared with Al-Hassani and AlSenaidi results of genetic testing29,30, but this should not delay the clinical diagnosis and implementation of life-saving measures. In the treatment strategy that was used in our patients, An excellent response was defined as a greater than $90 \%$ reduction in symptoms and a reduction of ventricular arrhythmias. In patients who responded well to $\mathrm{BB}$ with a negative family history of SCD, no ICD was implanted. In patients with LQTS1, we achieved almost $85 \%$ reduction in symptoms and ventricular arrhythmias (VA) incidence was monitored through the implanted ICD or by a Holter monitor, while in the LQT2 patients, an improvement was noticed in $45 \%$ of patients. In LQT3 patients, only one of four (25\%) patients improved slightly. These findings are similar to those 
of Moss and Vincent.18,19 However, the efficacy of BB was higher with LQT1 than with LQT2 and LQT3 compared to the less-common LQT.18,19 BB is recommended as a first-line therapy in most patients with LQTS. The 38 patients who received ICD were followed for 5-8 years, and 18 (47\%) patients developed VF/VT despite the maximum BB dose. These patients were treated successfully by the device through direct - current DC shock (DC-shock). Two pediatric patients died after repeated VF and repeated unsuccessful shocks. These results are comparable to a series that was reviewed in Schwartz's series 2010.25 The four patients who needed LCSD unfortunately could not be offered this therapy and two of them died with repeated DC-shocks and two patients were lost to follow-up. Conclusion: LQTS is a serious clilinical problem which needs to be diagnosed in patients present with symptoms of syncope or palpitation.Misdiagnosing the syndrome may lead to serious outcome.In Iraq this is the first report which will orient physicians, paediatricians to the this fatal diease.

\section{References:}

1. Schwartz P, Crotti L, Insolia R. Long-QT syndrome. Circulation Arrhythmia Electrophysiol. 2012; 5:868-877.

2. Abrams D, MacRae CA. Long QT syndrome. Circulation. 2014; 129:1524-1520.

3. Schwartz PJ, Crotti L. Long QT and short QT syndromes. In Zipes DP, Jalife J, eds. Cardiac Electrophysiology: From Cell to Bedside. Philadelphia, PA: Elsevier/Saunders; 2009:731-744. 4. Locati EH, Zareba W, Moss AJ,Schwartz PJ,Vincent GM,Lehman GM, et al. Age and sex related differences in clinical manifestations in patients with long-QT syndrome: Findings from the International LQTS Registry. Circulation. 1998;97(22):2237-2244.

5. Wilde AA, Moss AJ, Kaufman ES. Clinical aspects of type 3 long-QT syndrome: An international multicenter study. Circulation. 2016;134(12);872882.

6. Brignole $M$, Albeni $P$, Benditt D, Bergfeldt L, Blanc JJ, Erik $P$ et al. Guidelines on the management of syncope, update 2004. Europace. 2004; 6:467-537.

7. Moya A, Sutton $R$, Ammirati $F$,. Blanc $J J$, Brignole M, Johannes B. Dahm JB, et al. Guidelines on the management (diagnosis and management) of syncope. 2009. The Task Force for the diagnosis and, management of syncope of the European Society of Cardiology (ESC) version 2009. Euro H J. 2009:30:263-71.

8. MacCormick JM, McAlister H, Crawford $J$, French JK, Crozier I, Shelling AN et al. Misdiagnosis of long QT syndrome as epilepsy at first presentation. Ann Emerg Med. 2009; 54:26-32.

9. Schwartz PJ, Stramba-Badiale $M$, Crotti L, Pedrazzini M,Besana A, Bosi G, et al. Prevalence of the congenital long-QT syndrome. Circulation. 2009; 120:1761-1767.
10. Chen L, Marquardt ML, Tester DJ, Sampson KJ, Ackerman MJ, Kass RS. Mutation of an A-kinaseanchoring protein causes long-QT syndrome. Proc Natl Acad Sci USA. 2007; 104:20990-20995.

11. Kapa S, Tester DJ, Salisbury BA, Harris-Kerr $C$, Pungliya MS, Alders $M$ et al. Genetic testing for long-QT syndrome: Distinguishing pathogenic mutations from benign variants. Circulation. 2009; 120:1752-1760

12. Westenskow P, Splawski I, Timothy KW, Keating MT, Sanguinetti MC. Compound mutation cause sever long-QT syndrome. Circulation. 2004; 109:1834-1841.

13.Moss AJ, Robinson JL, Gessman L, Gillespie $R$, Zareba W, Schwartz PJ et al. Composition of clinical and genetic variables of cardiac events associated with loud noise versus swimming among subjects with the long-QT syndrome. Am J Cardiol. 1999; 84:876-879.

14.Ali RHH, Zareba W, Moss AJ,_Tester DJ, . Valdivia CR, Makielski JC, et al. Clinical and genetic variables associated with acute arousal and non-arousal-related cardiac events among subjects with long QT syndrome. Am J Cardiol. 2000;85:457461.

15.Spazzolini C, Mullally J, Moss AJ, Schwartz PJ, McNitt S, Ouellet G, et al. Clinical implications for patients with long $Q T$ syndrome who experienced a cardiac event during infancy. J Am Coll Cardiol. 2009;54(9):832-837.

16.Goldenberg I, Moss AJ, Petyerson DR,McNitt S,Zareba W, Andrews A, et al. Risk factors for aborted cardiac arrest and sudden cardiac death in children with the congenital long-QT syndrome. Circulation. 2008; 117:2184-2191.

17.Seth R, Moss AJ, McNitt S, Zareba W, Andrews $M L, Q i M$, et al. Long $Q T$ syndrome in pregnancy. $J$ Am Coll Cardiol. 2007;49(10):1092-1098.

18.Moss AJ, Zareba W, Hall WJ, Schwartz PJ, Crampton RS, Benhorin J,et al. Effectiveness and limitations of bet-blocker therapy in congenital longQT syndrome. Circulation. 2000; 101:616-623.

19.Vincent GM, Schwartz PJ, Denjoy I,Swan H, Bithell C, Spazzolini C, et al. High efficacy of betablockers in long- QT syndrome type 1: Contribution of noncompliance and QT-prolongation drugs to the occurrence of bet-blockers treatment" failures. Circulation. 2009; 119:215-221.

20.Goldenburg I, Horr S, Moss AJ, Lopes CM, Barsheshet A, McNitt S, et al. Risk for life threatening cardiac events in patients with genotypeconfirmed long-QT syndrome and normal ranged $Q T$ intervals. J Am Coll Cardiol. 2011; 57:51-59.

21.Priori SG, Schwartz PJ, Napollitano C,Bloise R,Ronchetti E, Grillo M, et al. Risk stratification in the long-QT syndrome. $N$ Engl J Med. 2003; 348:1866-1874.

22.Malfatto G, Beria G, Sala S, Bonazzi O, Schwartz PJ. Quantitative analysis of $T$ wave abnormalities and their prognostic implications in idiopathic long QT syndrome. J Am Coll Cardiol. 1994; 23:296-301. 23.Aziz PF, Tanel RE, Zelster IJ. Congenital long QT syndrome and 2:1 atrioventricular block: An 
optimistic outcome in the current era. Heart Rhythm. 2010;7(6):781-785.

24.Schwartz PJ, Priori SG, Cerrone M, Spazzolini C, Odero A, Napolitano $C$, et al. Left cardiac sympathetic denervation in the management of highrisk patients affected by the long-QT syndrome. Circulation. 2004; 109:1826-1833.

25.Schwartz PJ, Spazzolini C, Priori SG, Crotti L, Vicentini A, Landolina $M$, et al. Who are the long$Q T$ syndrome patients who receive an implantable cardioverter - defibrillator and what happens to them? Data from the European Long-QT Syndrome Implantable Cardioverter-Defibrillator (LQTS ICD) Registry. Circulation. 2010:122:1272-1282.

26.Zareba W, Moss AJ, Daubert JP, Hall WJ, Robinson JL, Andrews M.et al. Implantable cardioverter defibrillator in high-risk long $Q T$ syndrome patients. J Cardiovasc Electrophysiol. 2003; 14:337-341.

27.Haissaguerre $M$, Extramiana $F$, Hocini M, Cauchemez B, Jaïs P, Cabrera JA,et al. Mapping and ablation of ventricular fibrillation associated with Long-QT and Brugada syndromes. Circulation. 2003; 108(8):925-928.

28.Bdier AY, Al-Ghamdi S, Verma PK,Dagriri K, Alshehri B,Jiman OA. et al. Autosomal recessive long $Q T$ syndrome, type 1 in eight families from Saudi
Arabia. Mol Genet Genomic Med. 2017;5(5):592601.

29.AlSenaidi KS, Wang G, Zhang L, Beer DA, Alfarqani AM, Almaskaryi SN. Long QT syndrome, cardiovascular anomaly and findings in ECG-guided genetic testing. IJC Heart Vessel. 2014; 4:122-128. 30.Al-Hassani ZN, Al-Fayyadh M, Al-Ghamdi B, Shafaquat A, Mallawi Y, Al-Hadeq F. Clinical profile and mutation spectrum of long QT syndrome in Saudi Arabia: The impact of consanguinity. Heart Rhythm. 2017;14(8):1191-1199.

31.Al-Mousawi AAM, Al-Saedi KA, Shokry F, Nassir $S F$. Jervell and Lange-Nielsen syndrome (case report) Jervell and Lange-Nielsen syndrome (prolonged QT interval and hearing loss). Journal of the Faculty of Medicine Baghdad 2016: 58(1). :98101)._DOI: https://doi.org/10.32007/med.1936/jfac medbagdad.v58i1.20

32. Msayer KH, QT interval analysis in type 2 diabetic patients. Journal of the Faculty of Medicine Baghdad 2010;52(4):462-67.

33.Dawood HN, Al-Hadithi MAK. QTc Prolongation in Patients on Antipsychotic Drugs. Journal of the Faculty of Medicine Baghdad 2013;55(1):33-7. DOI: https://doi.org/10.32007/jfacmedbagdad.v133$37 \% 25$

\section{الحالة السريرية لمتلازمة استطالة ك ت، دراسة سلسلة حالات في العراق}

د. عمار طالب الحمدي

المقدمة: ان متلازمة استطالة ال ك ت سبب مهم للوفاة بسبب لانظميات القب البطينية وتتميز بتغيرات تخطيط القلب المتمثلة باستطالة فترة ال ك

هدف الدراسة: دراسة الوضع السريري والتو عية السريرية لمتلازمة استطالة ال ك ت لتقلقيل عدم تشخيص هذه الحالة المميتة.

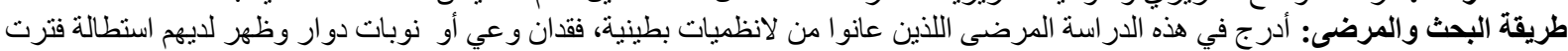

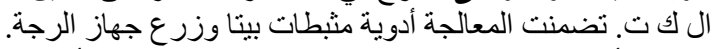

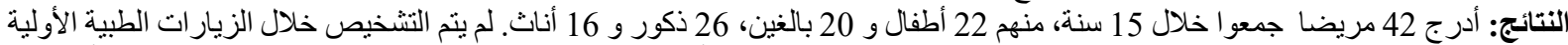

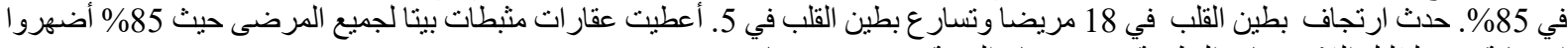

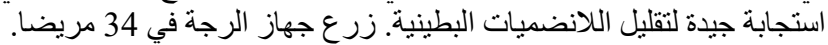

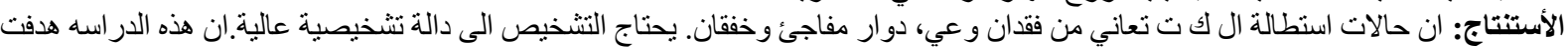

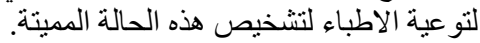

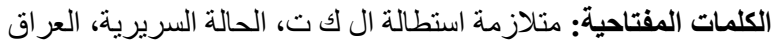

